\title{
Nevardarbīgās pretošanās dokumenti: ceturtais sējums ceḷā pie lasītāja
}

Recenzija par grāmatu: Nevardarbīgā pretošanās: Latvijas neatkarības atgūšana dokumentos (1945-1991). 4. sējums. Latvijas neatkarības idejas uzturēšana trimdā (1945-1991). Rīga 2017, 388 Ipp. ISBN 9789934851575

\section{Valdis Blūzma}

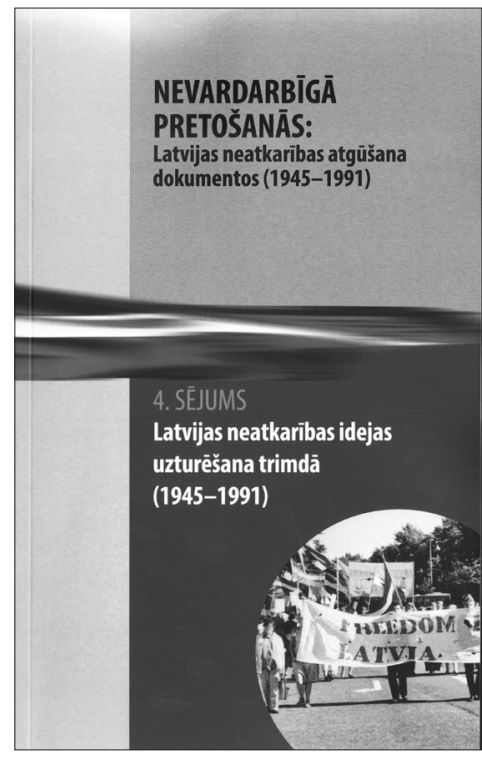

Dokumentu izdevumu sērija "Nevardarbīgā pretošanās: Latvijas neatkarības atgūšana dokumentos", kas top Latvijas Zinātņu akadēmijas (LZA) Baltijas Stratēǵisko pētījumu centrā (BSPC), tika aizsākta ar 2013. gadā iznākušo 1. sējumu "Nevardarbīgā pretošanās padomju okupācijas režīmam (1945-1985)", ${ }^{1}$ kurš tika sagatavots un publicēts valsts pētījumu programmas "Nacionālā identitāte" ietvaros (sējuma dokumentu sastādītāji vēsturnieki Heinrihs Strods un Jānis Riekstiņš). Tam sekoja 2. sējums "Atmodas laiks (1986. gada jūlijs - 1990. gada maija sākums"), ${ }^{2}$ kas nāca klajā 2015. gadā valsts pētījumu programmas "Letonika" ietvaros (sējuma dokumentu sastādītājs vēsturnieks Valdis Blūzma). Tajā pašā gadā tika izdots arī dokumentu izdevumu sērijas 3. sējums "Pārejas periods (1990. gada 4. maijs - 1991. gada 21. augusts)"33 (sējuma sastādītājs jurists un politologs Tālavs Jundzis). 
Divus gadus vēlāk lasītājs in saṇēmis 4. sējumu "Latvijas neatkarības idejas uzturēšana trimdā (1945-1991)", ${ }^{4}$ kas publicēts projekta "Latvijas valstiskās neatkarības atgūšanas pieredze, mācības un starptautiskā nozīme" ietvaros. Sējuma sastādītāja, ievada un komentāru autore ir vēsturniece Kristīne Beķere, savukārt šī sējuma, kā arī visu iepriekšējo dokumentu sērijas sējumu zinātniskais redaktors - BSPC vadītājs Tālavs Jundzis.

Kādas ir īpatnības, kuras atškir 4. sējumu no trim iepriekšējiem sējumiem? Pirmie trīs bija veltīti nevardarbīgajai pretošanās kustībai Latvijas teritorijā pret Padomju Savienības uzspiesto politisko režīmu, sākot ar 1945. gadu, kad Padomju Savienība Otrā pasaules kara rezultātā atjaunoja savu varu 1940. gadā okupētajā Latvijā, un beidzot ar 1991. gada augustu, kad pēc reakcionāro spēku sarīkotā Maskavas puča sagrāves PSRS bija spiesta atzīt Baltijas valstu neatkarības atjaunošanu.

Savukārt 4. sējums atspoguḷo latviešu politiskās emigrācijas - trimdas (termins izvēlēts, lai pasvītrotu, ka izceḷošanai no Latvijas bija piespiedu raksturs, ko noteica nesamierināma attieksme pret padomju okupācijas režīmu) cīṇu par to, lai tiktu īstenota Latvijas valsts atjaunošanas ideja visā Latvijas okupācijas vēsturiskajā periodā no 1945. gada pavasara līdz 1991. gada augustam. Pievēršoties termina "trimdinieki" izcelšanās vēsturei, K. Beḳere sējuma ievadā atzīmējusi, ka, "uzsverot piespiedu atrašanās ārpus savas valsts politisko aspektu - Baltijas valstu nelikumigo okupāciju un inkorporēšanu PSRS, Vācijas bēgḷu nometnēs nonākušie latvieši paši sevi nodēvēja par trimdiniekiem" (17. lpp.). Latviešu trimdas politiskās akcijas Rietumu demokrātiskajās valstīs cīṇā par Latvijas neatkarības atjaunošanu pamatoti jāatzīst par nevardarbīgu pretošanos padomju okupācijas varai, kaut arī tā norisinājās nevis anektētās un PSRS inkorporētās Latvijas teritorijā, bet demokrātiskajās Rietumvalstīs, kuras lielākoties nelika šḳēršḷus trimdas nevardarbīgajām politiskajām aktivitātēm. ${ }^{5}$ Nevardarbīgo pretošanos Latvijā un Rietumos vienoja politiskais mērkis - Latvijas valsts atjaunošana. Arī pretinieks nevardarbīgās pretošanās kustībai Latvijā un trimdas politiskajā cīnā bija viens un tas pats - Padomju Savienības komunistiskais režīms. Atšksirīgi bija pretošanās apstākḷi Rietumos trimdinieki varēja brīvi un atklāti paust savus politiskos centienus atšķirībā no okupētās Latvijas, kur bargu represiju draudu apstākḷıs nevardarbīgās pretošanās akcijām līdz padomju režīma liberalizācijai 80. gadu otrajā pusē lielākoties bija raksturīga anonimitāte, slepenība.

Labvēlīgs faktors, lai aktivizētu trimdinieku cinnu par Latvijas neatkarības atjaunošanu bija t. s. aukstais karš respektīvi ASV un PSRS un abu superlielvalstu sabiedroto militāri politiskā konfrontācija, kura gan nepārauga tiešā bruṇotā konfliktā, bet kuras pastāvīgs elements bija bruṇošanās drudzis no abām pusēm, lai ar tā palīdzību vismaz nodrošinātu pušu militāro paritāti. Bez tam ASV (kur izveidojās lielākā latviešu trimdinieku kopiena) kopš 1940. gada îstenotā Baltijas valstu inkorporācijas PSRS neatzīšanas doktrīna nodrošināja stabilu politisku atbalstu latviešu trimdinieku centieniem pēc Latvijas neatkarības atjaunošanas.

K. Beķere objektīvi atspogul,o faktu, ka sociāli un politiski aktīvi mītnes valstīs bija nebūt ne visi latviešu diasporai piederīgie, bet vērā n,emams mazākums, kas iesaistījās trimdas latviešu kultūras dzīves organizācijā un nacionālās identitātes saglabāšanā. Pētniece arī atzīmējusi, ka apstākḷi, kādos trimdinieki veica politiskās aktivitātes dažādās mītnes valstīs, atškīinās atkarībā no tās vai citas valsts ārpolitiskā kursa pret Padomju Savienību, kā arī no valsts politiskā režīma, tā attieksmes pret emigrantu politiskajām aktivitātēm. Dažkārt pat vēlēšanu 
rezultāti tajā vai citā Rietumu valstī, nākot pie varas kreisākiem politiskajiem spēkiem, kuri bija orientēti uz attiecību attīstīšanu ar PSRS, nelabvēlīgi ietekmēja trimdas cīnu par Baltijas valstu prettiesiskās aneksijas neatzǐšanu. Šādas situācijas atspoguḷotas vairākos krājumā ievietotos dokumentos. Tā 1961. gada 15. aprīlī Baltijas valstu pārstāvji izteica protestu pret jaunievēlētā Brazillijas prezidenta Žanio Kuadrosa (Jânio da Silva Quadros) valdības lēmumu slēgt Baltijas valstu pārstāvniecības saistībā ar Brazīlijas un PSRS diplomātisko attiecību atjaunošanu (dok. Nr. 42). Vairāki krājuma dokumenti (dok. Nr. 48, 49) liecina par trimdinieku cīṇu pret Lielbritānijas premjerministra Harolda Vilsona (Harold Wilson) vadītās leiboristu valdības lēmumu 60. gadu otrajā pusē nodot Padomju Savienībai Baltijas valstu zelta depozītus Anglijas Bankā, tā atzīstot PSRS par likumīgu Baltijas valstu pēcteci. 1974. gadā latviešu trimdas organizācijas izvērsa protestu kampanu pret Gofa Vitlama (Gough Whitlam) vadītās Austrālijas leiboristu valdības lēmumu "ņemt vērā pastāvošo realitāti" un atzīt Baltijas valstu inkorporāciju PSRS (dok. Nr. 65-69). 1975. gada Austrālijas parlamenta vēlēšanās leiboristi cieta sakāvi un jaunā labējā liberāḷu valdība, kuru atbalstīja baltieši, atcēla leiboristu valdības lēmumu par Baltijas valstu aneksijas atzīšanu de jure. K. Beķere atzīmējusi, ka "šim panākumam bija milzīga morāli pacilājoša un iedvesmojoša nozìme trimdas sabiedrïbai kā tādai" (38. 1pp.), to ar gandarījumu uztvēra latviešu trimdas organizācijas kā Austrālijā, tā arī ASV un citās mītnes valstīs. Savukārt neveiksmīga bija trimdinieku pretošanās lēmumam atzìt Baltijas valstu inkorporāciju PSRS (dok. Nr. 77, 80, 88), ko Jaunzēlandes leiboristu valdība Normana Kērka (Norman Kirk) vadībā pieṇēma 1974. gadā. 1975. gadā Jaunzēlandē pie varas nākusī Nacionālistu partija izlēma turpināt leiboristu politiku Baltijas jautājumā, atzīmējot, kā liecina publicētais Jaunzēlandes Ārlietu ministrijas dokuments (sk. dok. Nr. 77), cita starpā, samērā vāju baltiešu ietekmi uz Jaunzēlandes iekšpolitisko dzīvi. Publicētie dokumenti uzskatāmi rāda, ka latviešu trimdas organizāciju mērḳus nebūt ne vienmēr atbalstīja Rietumvalstu valdības, kas par prioritārām izvirzijja savas ārpolitiskās intereses atkarībā no tās vai citas valdošās partijas idejiskajām nostādnēm un attiecību rakstura, kuras tajā vai citā periodā veidojās starp Rietumu un Austrumu valstu bloku. Tādēl trimdas organizāciju darbībai pretošanās kustībā bija savdabīgas iezīmes - tai bija jānodrošina nemitīga aktivitāte, regulāri jānodarbojas ar savu interešu lobēšanu mītnes valsts, kā arī citu valstu varas struktūrās, jāparāda sevi kā vērā n,emamu spēku ielas akcijās utt., ietverot arī protesta akcijas ne vien pret padomju okupācijas režīmu Baltijas valstīs, bet arī pret tādiem mītnes valsts valdības soḷiem, kuri varētu būt bīstami trimdas politisko organizāciju izvirzītajiem mērḳiem. Lai nodrošinātu šo akciju lielāku efektivitāti, visu triju Baltijas valstu trimdinieki veidoja kopīgas organizācijas savu politisko interešu aizstāvībai.

4. sējumā ietverti kopskaitā 140 dokumenti, kuri aptver vēstures periodu no 1945. gada aprịla līdz 1991. gada augusta beigām. N̦emot vērā atlasīto dokumentu skaitu attiecībā pret atspogulojamo periodu, kḷūst skaidrs, ka krājumā iekḷauto dokumentu uzdevums ir sniegt lasītājam vispārīgu ieskatu par trimdas organizāciju aktivitātēm šajā laikmetā, un to arī ievadā ir uzsvērusi K. Bek̦ere.

Dokumenti sējumā ir ievietoti hronologiskā secībā, tomēr, lai atvieglotu lasītāju iepazišanos ar to vai citu gadu dokumentiem, sastādītāja ir sagrupējusi dokumentus piecās daḷās, kas veidotas pēc hronologiskā kritērija: 1) 1945-1956; 2) 1956-1972; 3) $1972-1976$; 4) 1977-1988; 5) 19881991. Kā šo periodu robežlīnijas norādītas 
izmainas trimdas organizāciju struktūrā, paaudžu nomaiņa to vadībā, jaunu mērķu un jaunu politiskās taktikas metožu izvirzišana. Saprotams, ka arī izmaināām starptautiskajās attiecībās, piemēram, tā saucamajai detantes (politiskā un militārā atslābuma) politikai 70 . gados, kā arī Latvijas iekšpolitiskajā stāvoklī, sākot ar Trešās atmodas pirmajiem gadiem, ir bijusi nenoliedzama ietekme uz trimdas politiskajām aktivitātēm. Runājot par trimdas vēstures periodizāciju, vēlama būtu lielāka precizitāte attiecībā uz periodu hronologiskajām robežām. Tā, piemēram, kā pirmajai, tā arī otrajai dokumentu dalai par robežu noteikts 1956. gads, bet, ieskatoties dokumentos, atklājas, ka pirmās daḷas pēdējais dokuments datêts ar 1955. gadu (dok. Nr. 28; Brīvās pasaules latviešu apvienības (BPLA) statūtu projekts), bet otrās daḷas pirmais dokuments datēts ar ELJA 1957. gada 4. augusta Etlingenes deklarāciju (dok. Nr. 29). Ar 1956. gadu datētu dokumentu nav ne pirmajā, ne otrajā periodā, līdz ar to, škiet, būtu pieticis, ka 1956. gadu kā BPLA organizatoriskās noformēšanās gadu (1970. gadā pārdēvēta par Pasaules Brīvo latviešu apvienību (PBLA)) atstātu 1. dạ̦ā, bet 2. daḷa tiktu iesākta ar 1957. gadu. Savukārt 2. daḷā kā beidzamais ievietots ar 1971. gada 13. jūniju datēts dokuments, līdz ar to 2 . dalu varēja droši noslēgt ar 1971. gadu, jo pirmais dokuments, kurš publicēts 3 . dạ̣ā, ir datēts ar 1972. gadu. 3. daḷas hronologiskie ietvari atbilst dokumentu datējumam, jo tā noslēdzas ar 1976. gada dokumentu un 4. daḷa iesākas ar 1977. gada dokumentu, bet varētu rasties jautājums, vai pamatoti 4. un 5. dalai noteikt kopīgu gadu - 1988. gadu - kā robežlīniju. Jāatzīmē, ka pretrunā ar hronoloğisko principu 4. dạ̣ā pēdējais ir dokuments, kurš datēts ar 1988. gada 24. jūniju, bet nākamajā 5. daḷā pirmais publicēts ar 1988. gada 16. martu datēts dokuments. Acīmredzot
1988. gada 24. jūnija dokumentu būtu pamatoti ievietot sējuma 5. dạ̣ā kā nākamo aiz šīs daḷas pirmā dokumenta. Tādā gadījumā iepriekšějo dokumentu daḷu varētu noslēgt ar 1987. gadu (diemžēel šis Rīgā ar t. s. kalendāra nemieriem bagātais gads palicis šajā sējumā bez kāda atspoguḷojuma trimdas reakcijā un akcijās), bet 5 . daḷa tad tiktu iesākta ar 1988. gadu.

Jāatzīmē, ka dokumentu krājuma veidošanā ñemti vērā arī citi kritēriji - tematiskais, ǵeogrāfiskais, dokumenta izgatavotāja kritērijs. Tā sastādītāja ir iekḷāvusi krājumā trimdas organizāciju un darbinieku dokumentus no daudzām pasaules valstīm - ASV, Lielbritānijas, Francijas, Rietumvācijas, Zviedrijas, Dānijas, Argentīnas, Brazīijas, Austrālijas, Kanādas, Jaunzēlandes, Venecuēlas. Kā jau uzsvērts ievadrakstā, lielāka trimdinieku politiskā aktivitāte bija vērojama valstīs, kur atradās daudzskaitlīgākās latviešu kopienas - ASV, Kanādā, Austrālijāâ, Lielbritānijā, VFR, Zviedrijā. Tomēr K. Beķere ir centusies pēc iespējas parādìt arī citās valstīs darbojušos trimdas organizāciju devumu cīnā par Latvijas neatkarības atjaunošanu. Attiecībā uz tematisko kritēriju ir jāmin trimdas politisko organizāciju un Latvijas diplomātisko pārstāvju vēstules mītnes un citu Rietumu valstu valdībām un parlamentiem, ANO un citām starptautiskajām organizācijām, Padomju Savienības politiskajiem līderiem, politisko spēku deklarācijas un trimdinieku konferenču rezolūcijas, vēstijjumi tautiešiem Latvijā, trimdas politisko organizāciju programmatiskie dokumenti un darbïbas pārskati, atzinumi un memorandi par Latvijas starptautiski tiesisko stāvokli, sarunas ar Rietumvalstu valdību vadītājiem un ministriem, atklātās vēstules un skrejlapas u. c.

Krājumā labi atspoguḷota Latvijas, Lietuvas un Igaunijas diplomātisko pārstāvju un latviešu, igauṇu un lietuviešu trimdinieku sadarbība cinnā par Baltijas valstu neatkarības atjaunošanu. Šì sadarbība sekmīgi 
norisinājusies gan atsevišķās mītnes valstīs (ASV, Lielbritānijā, Kanādā, Austrālijā, Jaunzēlandē, Argentīnā, Zviedrijā), gan starptautiskās baltiešu nevalstiskajās organizācijās - BATUN (Baltic Appeal to the United Nations - Baltiešu aicinājums Apvienotajām Nācijām), Pasaules Baltiešu apvienībā. Sevišku rezonansi guva divas baltiešu trimdinieku organizāciju akcijas 1985. gadā - Kopenhāgenas Baltiešu tribunāls (dok. Nr. 103) un Baltijas miera un brīvības kuğis (dok. Nr. 98). Krājumā ir labi atspoguḷoti atmodas gados uzsāktie trimdas organizāciju kontakti un sadarbība ar Latvijas neformālajām nacionāli demokrātiskajām organizācijām, piemēram, PBLA pārstāvju simpozijs ar Latvijas Tautas frontes, LNNK, Latvijas Atdzimšanas partijas pārstāvjiem Abrenē, Francijā, 1989. gada maijā. Atrodami arī dokumenti par Latvijas Tautas frontes struktūrvienību darbību trimdas mìtnes valstīs. Pēc tam, kad bija proklamēta Latvijas Republikas neatkarības atjaunošana, 1990. gada 4. maijā notika arī pirmā Latvijas valdības vadītāju (premjerministra Ivara Godmana un ārlietu ministra Jāṇa Jurkāna) neoficiālā tikšanās ar ASV valsts sekretāru Džeimsu Beikeru (James Baker) 1990. gada 20. jūlijā (dok. Nr. 129).

Ja runājam par dokumentu izgatavotāju kritērija izmantošanu krājumā, tad līdztekus trimdas politiskajām organizācijām un Latvijas diplomātiskā dienesta darbiniekiem jāmin arī Rietumvalstu valdību un tautas pārstāvniecības iestāžu izdotie dokumenti, kuros formulēta šo valstu nostāja Baltijas valstu suverenitātes jautājumā (dok. Nr. 65, 72, 77, 79), starptautisko organizāciju institūciju dokumenti par stāvokli Baltijas valstīs (dok. Nr. 94); PSRS iestāžu (galvenokārt Latvijas PSR VDK) dokumenti, kuros atspoguḷotas latviešu trimdinieku politiskās akcijas (dok. 57, 82, 130, 132), Latvijas iedzīvotāju vēstules starptautiskajām organizācijām (dok. Nr. 81).
Krājums atspoguḷo latviešu politiskās trimdas taktikas pakāpenisku mainu, ņemot vērā, cita starpā, izmaiṇas politiskajās attiecībās starp Rietumu un Austrumu bloku, pārejot no konfrontācijas uz detantes politiku. Ievērojama loma bija Eiropas Drošības un sadarbības apspriedei (EDSA), kurā 70. gados piedalījās 33 Eiropas valstis (izṇemot Albāniju), ASV un Kanāda un kuras Noslēguma aktā (1975) tika ietverta nostādne par pēckara robežu negrozāmību Eiropā. Latviešu trimdas organizācijas šo PSRS ierosināto principu uzṇēma ar neslēptām bažām, pamatoti uzskatot, ka tādā veidā Padomju Savienība cenšas legalizēt Baltijas valstu teritoriju aneksiju. Tas nozīmēja, ka Baltijas valstu trimdiniekiem ir jānodrošina atruna, kas neḷautu piemērot robežu negrozāmības principu attiecībā uz Baltijas valstu teritoriju. PBLA uzdevumā 1973. gadā Ķīes Universitātes (VFR) tiesību profesors, bijušais rīdzinieks Dītrihs Andrejs Lēbers izstrādāja juridiski pamatotu memorandu, kas norādīja uz nepieciešamību EDSA novērst Otrā pasaules kara prettiesiskās sekas attiecībā uz Baltijas valstīm (dok. Nr. 64). Enerǵiskas lobēšanas rezultātā PBLA izdevās panākt ASV prezidenta Džeralda Forda (Gerald Ford) 1975. gada 25. jūlija publisku paziņojumu, "ka nevienas teritorijas okupācija vai iegūšana, kas ir pretrunā ar starptautiskajām tiesībām, netiks atzìta par tiesisku" (dok. Nr. 72).

Tā kā EDSA Noslēguma akta tekstā šis princips netika atspogul,ots un ASV prezidents attiecīgu paziņojumu Helsinku konferencē nesniedza, latviešu trimdas organizācijas pielika visas pūles, lai ASV Senāts 1976. gada 5. maijā pieņemtu attiecīgu rezolūciju, ka ASV joprojām neatzīst Baltijas valstu prettiesisko sagrābšanu un aneksiju (dok. Nr. 79). Analogas rezolūcijas (nav publicētas šajā krājumā) pieṇēma arī ASV Kongresa Pārstāvju palāta (1975. gada 2. decembrī̄) un Kanādas parlaments (1976. gada 26. februārī). ${ }^{7}$ Jāatzīmē, ka 
Padomju Savienībā baltiešu trimdinieku akciju loma šo rezolūciju pieņemšanā tika ievērota un radīja neslēptu nepatiku. Tā triju Baltijas padomju republiku pētniecisko institūtu 1982. gadā izdotajā monogrāfijā "Baltijas reakcionārā emigrācija šodien" varam lasīt šādas emocionāli sakāpinātas rindas:

"Ar pilnu jaudu sāka darboties "Baltijas lobiju” mašĩna ASV kongresā un pirmām kārtām tā saucamā Apvienotā baltiešu komiteja. ${ }^{8}$ Reakcionāro spēku darbības rezultātā, ar emigrantu politikāṇnu lìdzdalību un arī bez tās, kongresā kā no pārpilnības raga sāka birt dažādi rezolūciju projekti par Latviju, Lietuvu un Igauniju."9

Turpmākajos gados latviešu trimdas politiskās organizācijas pievērsa uzmanību jautājumam par EDSA Noslēguma akta ievērošanu Latvijas teritorijā, lai nākamajās Eiropas apspriedēs varētu izvirzìt pretenzijas Padomju Savienībai par Noslēguma akta pārkāpumiem un prasīt no tās cilvēktiesību ievērošanu Latvijas teritorijā. Šajā kontekstā atzīmējama Aizputes iedzīvotāja Viestura Kalniņa vēstule Belgradas Eiropas Drošības un sadarbības konferencei (1977), ko angḷu valodā tulkoja un izplatīja PBLA un kas saturēja reālus faktus par reliǵisko brīvību ierobežojumiem Latvijā saistībā ar baptistu draudzi, kurā vēstules autors darbojies (dok. Nr. 81).

Šis darbs prasīja no trimdas organizācijām aktivizēt kontaktus ar Latvijas iedzīvotājiem, lai iegūtu reālus faktus par cilvēktiesību pārkāpumiem. Šeit interesi pelna Latvijas Sociāldemokrātiskās strādnieku partijas 1978. gada deklarācija par sakariem ar tautu Latvijā (dok. Nr. 86), tajā norādīts, ka "šodienas apstākḷ los tie ir vienīgais lìdzeklis brīvai un necenzētai informācijai tiklab par apstākḷiem demokrātiskajā pasaulè un latviešu darbību ārzemēs, kā arī par okupētās Latvijas dzìvi". Kritisks vērtējums tika sniegts to trimdas ekstrēmo aprindu nostājai, "kas vārdos iestājas par sakariem ar Latviju, bet praktiski no tās atsakās, katrā mēgeinājumā jau iepriekš saredzot nacionālo interešu nodevibu".

Būtiski atzīmēt, ka līdz nacionālās atmodas kustībai Latvijā 80. gadu otrajā pusē, kuru sekmēja PSRS komunistiskā režīma liberalizācija, trimdas organizācijas praktiski nemaz neizskatīja tādu Latvijas neatkarības atjaunošanas scenāriju, kas varētu izrietēt no Padomju Savienības politiskās sistēmas liberalizācijas, dodot iespēju Latvijas iedzīvotājiem brīvāk paust savu viedokli. Čehoslovākijas Komunistiskās partijas vadības uzsāktais politiskās sistēmas liberalizācijas kurss 1968. gadā parādīja, ka šāda komunistiskā režīma evolūcija liberālisma virzienā, notiekot paaudžu nomaiṇai Komunistiskās partijas vadībā, ir reāli iespējama, un, ja tā iesāktos Padomju Savienībā, tad šo procesu nevarētu bremzēt no ārienes kā Čehoslovākijā. Līdz 80. gadu vidum trimdas organizācijas paḷāvās vienīgi uz Rietumvalstu spiediena politiku pret PSRS Baltijas jautājuma risināšanā, cenšoties lobēt šajā virzienā Rietumu lielvalstis. Visai neatlaidīgi bija trimdas organizāciju, sevišķi BATUN, centieni panākt Baltijas valstu neatkarības atjaunošanu, iesaistot ANO (dok. Nr. 9, 40, 99, 121), bet tie visi bija neveiksmīgi, n,emot vērā, ka PSRS bija veto tiesības ANO Drošîbas padomē. Vēl vienu mēginājumu nodot Baltijas valstu jautājumu ANO dekolonizācijas apakškomisijai baltiešu trimdas pārstāvji centās īstenot, vēršoties pie Eiropas Parlamenta, kurš 1983. gada 13. janvārī pieņēma rezolūciju par stāvokli Igaunijā, Latvijā un Lietuvā (dok. Nr. 94), tomēr Eiropas Kopienu dalībvalstu ārlietu ministri nevirzijja Baltijas valstu jautājumu tālākai caurlūkošanai ANO dekolonizācijas apakškomisijā.

Vienīgi Latvijas Nacionālās atbrīvošanas frontes programmā (piencemta 1975. gada 21. augustā), kuru kā "alternativiu trimdas lìdzšinējai politikai" III Vispasaules latviešu jaunatnes kongresā Florefā (Beḷg̣ija) 
izstrādāja demogrāfiskā darba grupa (dok. Nr. 74), atrodamas šim laikam atškirīgas taktiskās nostādnes Latvijas neatkarības jautājuma risināšanā - tajā ierosināta pakāpenība komunistiskā režīma liberalizācijā un demontāžā Latvijā, kā tas praksē arī tika īstenots atmodas periodā. Programma nepārprotami rāda, ka tās sastādītāji ietekmējušies no EDSA rezultātiem, uzsverot: tie "pierāda, ka rietumtrimdai ir pienācis pēdējais laiks atmest ilūzijas par ASV un citu rietumvalstu drīzo palìdzïbu, kuras gadiem izplatija trimdas vecās konservativiās aprindas un kas vēl arī šodien ir to darbỉbas pamatā". Aktuālās prasības, kuru mērḳis bija pasargāt latviešu nāciju, tās valodu un kultūru, programmas autori nodalīja no pamatmērka - tautas gribas îstenošanas atbilstoši nāciju pašnoteikšanās tiesībām. Programmas autori paredzēja nodrošināt elementāras cilvēka tiesības un politiskās brīvības, pieprasot precīzi ievērot 1940. gada Latvijas PSR Konstitūcijas attiecīgos pantus, piemēram, 96. pantu (vārda, preses, sapulču, gājienu un demonstrāciju brīvība), 98. pantu (pilsoṇu dzīvokḷa neaizskaramība), 112. pantu (tiesības padomju vēlēšanās izvirzīt vairākus kandidātus bez Latvijas Komunistiskās partijas (LKP) iejaukšanās). Attiecībā uz tautas pašnoteikšanās tiesību īstenošanu programma ierosināja izmantot LPSR Konstitūcijas 15. un 31. pantu, lai sarīkotu Latvijas patieso pilsoṇu referendumu atbilstoši LPSR Konstitūcijā noteiktajai savienotās republikas tiesībai izstāties no PSRS. Programmā bija iekḷautas arī ekonomiskas, kultūras, izglītības prasības, nosakot obligātu latviešu valodas lietošanu padomēs, ministrijās, tautsaimniecības iestādēs un arī LKP sēdēs un kongresos. Programmā pamatoti tika aizrādīts, ka "vispārējās pārmaiñas notiks tikai Padomju iekšējo spēku maiñas rezultātā", un latviešu tauta tika aicināta atbalstīt krievu demokrātu opozīciju, norādot, ka "latvieši paši vien nepanāks režima mainu Latvijā”.
Jaunas iespējas Latvijas neatkarības idejas izplatīšanā pašā Latvijas teritorijā radās līdz ar paaudžu nomaiṇu Padomju Savienības Komunistiskās partijas (PSKP) vadībā un liberāli noskan,otā Mihaila Gorbačova nonākšanu PSKP Centrālkomitejas ǵnenerālsekretāra amatā. 80. gadu vidū Amerikas Latviešu apvienība (ALA) pēc jautājuma rūpīgas apsvēršanas pieṇēma saprātīgu lēmumu neiebilst pret ASV un PSRS pārstāvju Šatakvas konferences norisi Jūrmalā (1986. gada septembrī), atzīmējot, ka šajā gadījumā varētu izmantot vienreizēju izdevību "pacelt baltiešu jautājumu tik plaši kā vēl nekad", jo ASV pārstāvji varēs paziñot par Baltijas valstu okupācijas neatzīšanu publiskā forumā okupētās Latvijas teritorijā - pirmo reizi Padomju Savienības okupācijas vēsturē (dok. Nr. 106). Ar šādu paziņojumu ASV valdības vārdā, runājot latviešu valodā, konferencē uzstājās ASV prezidenta īpašais palīgs (Special Assistant) Džeks Metloks (Jack Matlock). Šì uzstāšanās izraisīja vērā ñemamu rezonansi pašā Latvijā un sekmēja atmodas kustības rašanos. Par Dž. Metloka pausto ASV valdības nostādni Baltijas valstu jautājumā atklāti vēstīja tolaik Latvijā populārākais laikraksts "Padomju Jaunatne", ${ }^{10}$ kamēr "Cīṇa" un preses aǵentūra Latinform noklusēja neērto informāciju. Krājumā ievietotajā ALA priekšsēēetāja Aristīda Lamberga 1986. gada 2. oktobra pateicības vēstulē Dž. Metlokam (dok. Nr. 107) pravietiski izskanēja vārdi: "Jūs esat ieguldījis latviešu tautas drosmē, un tas atmaksāsies nākamajos gados."

Atmodas periodā, kad no 1986. līdz 1988. gadam Latvijā tika nodibinātas vairākas nacionāldemokrātiskas sabiedriski politiskas organizācijas ar Latvijas Tautas fronti priekšgalā, trimdas organizācijas sāka attīstīt sadarbību ar tām kā organizatoriski politiskajā, tā arī materiāltehniskajā aspektā (dok. Nr. 111, 114, 122) un vērsās pie Rietumvalstu (Kanādas (dok. Nr. 112), 
Eiropas valstu (dok. Nr. 113)) valdībām ar lūgumu sniegt politisku un materiālu atbalstu Baltijas valstu nacionāldemokrātiskajiem spēkiem. Tā bija būtiska pārmaiņa trimdas organizāciju taktikā, kura iepriekš bija galvenokārt vērsta uz politiskām akcijām Rietumu pasaulē. Krājumā iekḷautā Daugavas Vanagu rezolūcija, kas pieņemta 1989. gada jūnijā (dok. Nr. 117), uzskatāmi parāda latviešu trimdas izpratni, ka tā laika situācijā "rietumvalstis nav ieinteresētas PSRS kā valsts kopïbas sadrumstalošanā un, liekas, nedarīs neko, lai veicinātu kādu citu attīstïbu". Kā rāda krājumā publicētie dokumenti (dok. Nr. 124, 125, 128, 133, 137), trimdas organizācijas, Latvijas diplomātiskie pārstāvji aktīvi centās panākt, lai Rietumvalstis atzītu 1990. gadā atjaunotās Baltijas valstis vismaz de facto, taču šie centieni atdūrās pret Rietumvalstu nostāju par katru cenu atbalstīt Gorbačovu pret konservatoru grupējumu, atsakoties no spiediena politikas pret PSRS vadību Baltijas valstu jautājumā. Šāda nostāja redzama arī tikšanās laikā starp Latvijas premjerministru Ivaru Godmani, ārlietu ministru Jāni Jurkānu un ASV valsts sekretāru Džeimsu Beikeru 1990. gada 20. jūlijā Vašingtonā, kuras laikā Dž. Beikers iebilda pret Latvijas atzīšanu no ASV puses, "jo to nav iespējams istenot praksē", bet aicināja Latvijas valdību vienoties ar M. Gorbačovu par kādu Latvijas "finlandizācijas" modeli (dok. Nr. 129), respektīvi, paklaušanos noteiktiem ārpolitiskiem ierobežojumiem, kurus tolaik nācās ievērot Somijai attiecībās ar PSRS. Ir pamats piekrist Eduarda Bruno Dekšña secinājumam, ka "Latvijas un pārējo Baltijas valstu neatkarības atgūšana neieklā̄āa nevienas Rietumvalsts diplomātiskajos būtiskajos centienos". ${ }^{11}$ Šì atziṇa lauj labāk novērtēt trimdas politiskās aktivitātes devumu, neatslābstoši cīnoties par Baltijas jautājuma izvirzī̌sanu starptautiskās politikas priekšplānā.

PSRS konservatīvo spēku sarīkotā 1991. gada augusta puča mērḳis bija centralizētas komunistiskas Padomju Savienības saglabāšana, un tā izgāšanās Maskavā mainīja politisko spēku samēru par labu Borisa Jeḷcina vadītajai Krievijas PFSR valdībai, kas iestājās par PSRS demontāžu. Rietumvalstis kḷuva atsaucīgas baltiešu trimdas aicinājumiem atzìt Baltijas valstu neatkarību (dok. Nr. 139, 140) un, nemaz nesagaidot PSRS Valsts padomes Baltijas valstu neatkarības atzīšanas aktu (1991. gada 6. septembrī), pieṇēma attiecīgus aktus par Baltijas valstu neatkarības atzīšanu vai arī diplomātisko attiecību atjaunošanu ar tām.

Dokumentu krājuma unikalitāte saistāma ar plašo arhīvu klāstu, kuros ir strādājuši pētnieki - līdztekus Latvijas arhīvos atrodamajiem dokumentiem publicēti arī dokumenti no ASV, Austrālijas, Jaunzēlandes, Lielbritānijas, Vācijas un Zviedrijas arhīviem, trimdas organizāciju un privātajiem arhīviem, pie tam lielākā daḷa krājumā iekļauto dokumentu ir pirmpublicējumi. Kopumā krājuma mērḳis - atspoguḷot trimdas politisko aktivitāšu geogrāfisko plašumu, tematisko daudzveidību, trimdas politiskās darbības attīstības tendences īstenots sekmīgi. Publicētie dokumenti l̦auj secināt, ka trimdas ieguldījums Latvijas neatkarības atjaunošanā bija nozīmīgs, būtiski sekmējot atbalstu nevardarbīgai Latvijas pretošanās kustībai pasaulē. Bez šaubām, vienmēr var vēlēties sīkāk izgaismot kādus trimdas darbības aspektus (piemēram, 40. gadu beigu - 50. gadu sākuma polemiku trimdā par emigrācijas valdības veidošanu), bet jāpatur vērā sējuma ierobežotais apjoms. Škikiet, ka lasītājam, it īpaši tādam, kuram nav priekšzināšanu par trimdas politisko aktivitāšu vēsturi, būtu bijis noderīgi, ja līdztekus rūpīgi izstrādātajam personu rādītājam būtu pievienots arī trimdas organizāciju (arī to, kurās darbojās visu triju Baltijas valstu trimdinieki) saraksts ar īsām norādēm, kad organizācija dibināta, kādi bijuši tās darbības mērḳi utt. Būtu 
arī bijis vēlams šì sējuma atsaucēs sniegt norādes uz tajā pieminēto dokumentu publikācijām iepriekšējos izdevuma sējumos. Piemēram, Eiropas Parlamenta 1983. gada 13. janvāra rezolūcijā par stāvokli Igaunijā, Latvijā un Lietuvā atrodamas atsauces uz 1979. gada 45 baltiešu parakstītu memorandu, kas publicēts "Nevardarbīgās pretošanās" dokumentu izdevuma 1. sējumā kā 39. dokuments.

Noslēgumā gribas izteikt pārliecību, ka sērijas "Nevardarbīgā pretošanās: Latvijas neatkarības atgūšana dokumentos" 4. sējums kḷūs noderīgs 20. gadsimta Latvijas vēstures pētniekiem, kā arī visiem tiem, kas interesējas par latviešu trimdas vēsturi.

\section{ATSAUCES UN SKAIDROJUMI}

${ }^{1}$ HEINRIHS STRODS, JĀNIS RIEKSTIN̦Š (sast.). Nevardarbīgā pretošanās: Latvijas neatkarības atgūšana (1945-1991) dokumentos. 1. sējums. Nevardarbīgā pretošanās padomju okupācijas režìmam (1945-1985). Rìga 2013, 290 lpp.

${ }^{2}$ VALDIS BLŪZMA (sast.). Nevardarbīgā pretošanās: Latvijas neatkarības atgūšana (1945-1991) dokumentos. 2. sējums. Atmodas laiks (1986. gada jūlijs - 1990. gada maija sākums). Rīga 2015, 416 lpp.

${ }^{3}$ TĀLAVS JundZIS (sast.). Nevardarbīgā pretošanās: Latvijas neatkarības atgūšana (1945-1991) dokumentos. 3. sējums. Pārejas periods uz pilnīgu valstiskās neatkarības atjaunošanu de facto (1990. gada 4. maijs - 1991. gada 21. augusts). Rìga 2015, 240 lpp.

${ }^{4}$ KRISTīNe BEĶERE (sast.). Nevardarbīgā pretošanās: Latvijas neatkarības atgūšana (1945-1991) dokumentos. 4. sējums. Latvijas neatkarības idejas uzturēšana trimdā (1945-1991). Rīga 2017, 388 lpp.

${ }^{5}$ Kā nozīmīgs iznēemums jāmin Vispasaules Latviešu jaunatnes kongresa rīkošanas aizliegums Rietumberlīnē 1968. gada jūlijā, bet arī šajā gadījumā runa bija nevis par pasākuma aizliegšanu, bet par tā pārcelšanu no Rietumu sabiedroto okupācijas varām pakḷautās pilsētas uz Rietumvāciju (sk. 4. sējuma dok. Nr. 52, 53).

${ }^{6}$ H. Res. 864 - Resolution expressing the sense of the House of Representatives that the signing in Helsinki of the Final Act of the Conference on Security and Cooperation in Europe did not change in any way the long-standing policy of the United States on nonrecognition of the Soviet Union's illegal seizure and annexation of the three Baltic nations of Estonia, Latvia, and Lithuania. Pieejams: https://www.congress.gov/bill/94th-congress/house-resolution/864? $r=864$ (skatīts 06.09.2018.).

7 Journals of the House of Commons of Canada, No. 253. 30 $0^{\text {th }}$ Parliament, $1^{\text {st }}$ Session: Vol. 121 , Pt. 2. Pieejams: http://parl.canadiana.ca/ (skatīts 06.09.2018.).

${ }^{8}$ Domāta Joint Baltic American National Committee, 1961. gadā baltiešu izveidotā organizācija ASV federālo likumdošanas struktūru un valdības lobēšanai.

${ }^{9}$ VALENTĪNS ŠTEINBERGS (red.). Baltijas reakcionārā emigrācija šodien: Lietuviešu, latviešu un igauṇu antikomunistiskā emigrācija imperiālisma kalpībā. Rīga 1982, 179. lpp.

10 JĀNIS İsLīicIs. Par svarīgāko tematu. In: Padomju Jaunatne, 17.09.1986., 1. 1pp.

${ }^{11}$ EDUARDS BRUNO DEKSNIS. Arhīvos atrodamās liecības par trimdas politiskajām aktivitātēm (1945-1991). In: TĀLAVS JUNDZIS (sast.). Latviešu trimdas loma Latvijas neatkarības idejas uzturēšanā: Apvienotā Pasaules latviešu zinātnieku III un Letonikas IV kongresa sekcijas materiāli. Riga 2011, 9.-30. lpp. 